\title{
Niezrównoważona konsumpcja i sposoby jej równoważenia
}

DOI: $10.19195 / 2083-7763.9 .3$

\section{Wstęp}

Nowy paradygmat rozwoju eksponuje cechę samopodtrzymywania. Zdefiniowano go po raz pierwszy w raporcie Brundtland, nadając mu następujące brzmienie: jest to rozwój zaspokajający potrzeby obecnych pokoleń, który nie odbiera jednocześnie możliwości do zaspokajania potrzeb kolejnym pokoleniom ${ }^{1}$. Ten paradygmat inspiruje oraz wyznacza zróżnicowane kierunki dla aktualnych procesów gospodarowania. Do kluczowych sfer jego operacjonalizacji należy innowacyjna koncepcja zrównoważonej konsumpcji. Nowy paradygmat rozwoju wprost wskazuje jedno uszczegółowienie nowego paradygmatu konsumpcji, który większość dokumentów strategicznych określa konsumpcją zrównoważoną ${ }^{2}$ lub trwałą ${ }^{3}$ W polskich dokumentach prawnych można znaleźć elementy spójne z koncepcją zrównoważonego rozwoju ${ }^{4}$. Ekonomia przybierająca cechy koncepcji zrównoważonego rozwoju pozwala na racjonalne gospodarowanie zasobami bę-

\footnotetext{
${ }^{1}$ Report of the World Commission on Environment and Development, Our Common Future, Oxford, 11.12.1987.

2 Program działań na rzecz zrównoważonej produkcji i konsumpcji, Ministerstwo Gospodarki, 2009, projekt.

${ }^{3}$ H. Jastrzębska-Smolaga, W kierunku trwałej konsumpcji. Dylematy, zagrożenia, szanse, Warszawa 2000.

${ }^{4}$ Konstytucja RP z 1997 roku (Dz.U. z 1997 r. Nr 78, poz. 483).
} 
dącymi w niedoborze, mającymi także alternatywne wykorzystanie ${ }^{5}$. W artykule zaprezentowany zostanie ten model, a także jego przeciwieństwo - zagadnienie niezrównoważonej konsumpcji i społeczeństwa konsumpcyjnego.

\section{Cecha zrównoważonego rozwoju}

Nowy paradygmat zintegrowanego rozwoju, funkcjonujący także pod nazwami „zrównoważony”, „trwały” lub „samopodtrzymujący”, eksponuje kolejno trzy cechy rozwojowe - samopodtrzymywanie, równoważenie i trwałość ${ }^{\text {. Każda }}$ $\mathrm{z}$ nich odpowiada za inne cele ${ }^{7}$ :

- samopodtrzymywanie (sustensywność) jest podtrzymywaniem sprawiedliwości międzypokoleniowej i wewnątrzpokoleniowej, przy jednoczesnym zachowaniu wydolności (pojemności) środowiskowej;

- trwałość oznacza, że niezbędne jest zachowanie każdego rodzaju kapitału, zarówno w aspekcie jakościowym, jak i ilościowym; nie ma możliwości substytucji w obszarze określonego kapitału; kapitały o pochodzeniu antropogenicznym i przyrodniczym są wobec siebie komplementarne ${ }^{8}$;

- zrównoważenie jest uwzględnianiem zrównoważonych aspektów ekologicznych, społecznych i ekonomicznych w rozwoju.

Istotą zrównoważonego rozwoju jest powiązanie rozwoju społecznego i gospodarczego przez zapewnienie dostępu do zasobów odnawialnych oraz nieodnawialnych ze wzrostem jakości życia w czystym środowisku. Wzrost gospodarczy powinien zapewniać bardziej efektywne wykorzystanie surowców i innych zasobów przyrody, racjonalizację zużycia energii i pracy, a także rozwój ekologicznych technologii oraz ochronę dziedzictwa przyrodniczego i kulturowego. Zrównoważony rozwój jest humanitarną koncepcją globalnego rozwoju, której podstawowym wyznacznikiem jest poprawa jakości życia i dobrobytu ludzkości w warunkach ograniczonych zasobów naturalnych, z uwzględnieniem długookresowych skutków rozwoju przemysłu. Koncepcja ta zakłada wspólną odpowiedzialność i solidarność obecnych i przyszłych pokoleń ${ }^{9}$. Nadrzędnym założeniem jest zapewnienie sprawiedliwego wzrostu, w którym swój udział ma całe społeczeństwo.

${ }^{5}$ T. Sowell, Ekonomia dla każdego, przeł. J.M. Fijor, Chicago-Warszawa 2000, s. 66.

6 T. Borys, Wybrane problemy metodologii pomiaru nowego paradygmatu rozwoju - polskie doświadczenia, „Optimum. Studia Ekonomiczne” 2014, nr 3 (69), s. 10.

7 T. Borys, Jak mierzyć postępy we wdrażaniu zrównoważonego rozwoju?, [w:] Barometr zrównoważonego rozwoju, red. K. Kamieniecki, B. Wójcik, Warszawa 2009, s. 58.

8 T. Borys, Koncepcja równoważonego rozwoju w naukach ekonomicznych, [w:] Edukacja dla zrównoważonego rozwoju, t. 2, red. B. Poskrobko, Warszawa- Białystok 2010, s. 11.

9 J. Adamczyk, T. Nitkiewicz T., Prognozowanie zrównoważonego rozwoju, Warszawa 2007, s. 25. 


\section{Cele zrównoważonej konsumpcji i jej powiązanie z produktami zrównoważonymi}

W pewnym zakresie dorobek ekonomii środowiska jest wykorzystywany przez zrównoważoną konsumpcję ${ }^{10}$. Ze względu na utrzymujący się w ekonomii środowiska postulat ekonomizacji środowiska przyrodniczego (opierającej się na wrażliwej zasadzie trwałości rozwoju) ten zakres jest ograniczony - cele ekonomiczne wraz z uwarunkowaniami traktowane są nadrzędnie w odniesieniu do potrzeb i środowiskowych uwarunkowań, jak również celów ochrony środowiska; w tym zakresie ujawniają się deficyty aksjologiczne (ze względu na egocentryczną postawę $)^{11}$. Istotną rolę w zrównoważonej konsumpcji odgrywa zrównoważony konsument, który ma wysoką wrażliwość i świadomość ekologiczną ${ }^{12}$. Podstawowe założenie ekonomii ekologicznej — jedność środowiska i człowieka - jest uwzględniane przez zrównoważoną konsumpcję. Konieczne zatem wydaje się utrzymywanie sprawnego ekosystemu dla dobra społeczeństw ${ }^{13}$. Pojęcie „konsumpcja” (od ang. „konsumować”), wywodzące się od łac. consumptio, pierwotnie miało znaczenie pejoratywne ('marnować, roztrwaniać, używać) ${ }^{14}$. Znaczenie zaczęło się zmieniać w XIX wieku, gdy jego charakter zaczął być neutralny określano, że jest to spożywanie dóbr, natomiast konsumentem określono kogoś nabywającego towary lub ich użytkownika ${ }^{15}$. Wielu konsumentów jest zainteresowanych alternatywnymi sposobami na zaspokojenie swoich potrzeb, które będą uwzględniać interesy pozostałych konsumentów i producentów środowiska społecznego oraz przyrodniczego ${ }^{16}$. Zrównoważona konsumpcja obejmuje zatem takie zagadnienia, jak: ludzkie potrzeby, jakość życia, sprawiedliwość, efektywne używanie zasobów, zmniejszenie procesu powstawania odpadów, dobre zdrowie i bezpieczeństwo nabywcy ${ }^{17}$. Zrównoważona konsumpcja to sposób korzystania

${ }^{10}$ H. Rogall, Ekonomia zrównoważonego rozwoju. Teoria i praktyka, przeł. J. Gilewicz, Poznań 2010, s. 25.

11 T. Borys, Nowe kierunki ekonomii środowiska i zasobów naturalnych w aspekcie nowej perspektywy finansowej Unii Europejskiej, „Ekonomia i Środowisko” 2013, nr 1 (44), s. 18.

12 T. Borys, Problemy zrównoważonej konsumpcji, [w:] Rozwój zrównoważony. Teoria i praktyka, red. B. Fiedor, R. Jończy, Wrocław 2009; S. Zaremba-Warnke, Konsumeryzm a procesy integracji $i$ dezintegracji, [w:]Procesy integracyjne i dezintegracyjne we współczesnej gospodarce, red. B. Polaszkiewicz, J. Boehlke, „Ekonomia i Prawo” 8, 2012, nr 1.

13 S. Dziedzic, L. Woźniak, Ekonomia ekologiczna (zielona) oraz ekonomia endogeniczna we wspieraniu innowacji w rozwoju regionu, Rzeszów, 2013.

${ }^{14}$ Konsumpcja, [hasło w:] A. Bańkowski, Etymologiczny słownik języka polskiego, Warszawa 2000, s. 785.

${ }^{15}$ Konsument, [hasło w:] Słownik 100 tysięcy potrzebnych słów, red. J. Bralczyk, Warszawa 2005, s. 315 .

${ }^{16}$ B. Poskrobko, Ekonomia zrównoważonego rozwoju w świetle kanonów nauki, WSE, Białystok 2011.

17 O. Mont, A. Plepys, Sustainable consumption progress: should we be proud or alarmed?, „Journal of Cleaner Production" 2008, nr 16, s. 532. 
z dóbr, który przyniesie lepszą jakość życia, wówczas gdy zostaną spełnione dwa warunki:

- podczas realizacji tych celów nabywca zdecyduje się radykalnie zmniejszyć zużycie energii i zasobów naturalnych, emisję zanieczyszczeń i odpadów, a także nie będzie wykorzystywać toksycznych materiałów;

- podniesienie jakości życia obecnych pokoleń bez ograniczania kolejnych w odniesieniu do zaspokajania ich potrzeb (zasada międzypokoleniowej sprawiedliwości $)^{18}$.

Świadoma konsumpcja polega na postępowaniu zgodnie z zasadą 3R (reduce, reuse, recycle). Ma ona na celu ograniczenie nabywania jedynie do dóbr niezbędnych klientom, którzy powinni używać ich wielokrotnie, a w efekcie właściwie je przetwarzać $^{19}$. Konsumpcja trwała i zrównoważona ma opierać się na rozsądnych wyborach, konsumenckiej wstrzemięźliwości, ograniczeniu marnotrawstwa podczas zaspokajania potrzeb ${ }^{20}$, a także na nabywaniu produktów zrównoważonych. Są nimi:

- bezpieczne produkty, spełniające międzynarodowe standardy środowiskowe oraz etyczne w całym cyklu życia produktu, a także trwałe i oszczędne;

- produkty, które podczas ich wytwarzania (zmniejszenie bezrobocia) i użytkowania pozytywnie oddziałują na nabywców i lokalną społeczność;

- produkty z profesjonalną etykietą i informacjami proekologicznymi i prospołecznymi, a także na temat prawidłowego użytkowania oraz procesie ich utylizacji;

— produkty, które przewyższają tradycyjne produkty pod względem użyteczności i jakości użytkowania ${ }^{21}$.

Podstawą konsumpcji zrównoważonej jest propagowanie świadomych, racjonalnych postaw oraz konsumenckich zachowań, które opierają się na ważnych wartościach $^{22}$. Podczas decyzji zakupowych konsument, nabywając określone dobro, nie skupia się jedynie na zrealizowaniu swoich potrzeb, lecz na konsekwencjach dla środowiska naturalnego. Niezbędne jest uwzględnianie dobra otaczającego świata ${ }^{23}$. Dzięki zrównoważonym wyborom konsumenckim nabywane są artykuły u lokalnych dostawców, ekologiczne, zdrowe, z poszanowaniem przyrody, sprawiedliwego handlu, pochodzące $\mathrm{z}$ recyklingu, a także nietestowane

${ }^{18}$ H. Jastrzębska-Smolaga, op. cit, s. 73.

${ }^{19}$ M. Krzystkiewicz, A. Rok, Spacerownik po świadomej konsumpcji - Kraków, Kraków 2008, s. 8.

${ }^{20}$ S. Czaja, A. Becla, Czterech jeźdźców ekologicznej zagłady we współczesnym świecie, [w:] Trendy i wyzwania zrównoważonego rozwoju, red. B. Kryk, Szczecin 2011, s. 48.

${ }^{21}$ Przez zrównoważoną konsumpcję do zrównoważonego rozwoju, Ministerstwo Gospodarki 2012.

22 J.A. Ottman, Green Marketing: Challenges and Opportunities for the New Marketing Age, Lincolnwood 2003.

${ }^{23}$ R. Harrison, R. Newholm, D. Shaw, Pressure groups, campaigns and consumers, [w:] The Ethical Consumer, red. R. Harrison, T. Newholm, D. Shaw, London 2005, s. 2. 
na zwierzętach, co pozwala uchronić ogromną liczbę zwierząt przed torturami i śmiercią w męczarniach, po poddaniu ich wielu eksperymentom ${ }^{24}$. Nadrzędnym celem zrównoważonej konsumpcji i zrównoważonego rozwoju jest trwała poprawa jakości życia, będąca subiektywnym poczuciem dobrostanu w jego społecznych, psychicznych, fizycznych i duchowych aspektach ${ }^{25}$.

\section{Zakłócenia w konsumpcji — konsumpcja niezrównoważona}

Zaprzeczeniem zrównoważonej konsumpcji jest konsumpcja niezrównoważona, mająca dwa oblicza. Pierwszym z nich jest konsumpcja nadmierna, a drugim - niedostateczna, poniżej poziomu pozwalającego zaspokoić podstawowe potrzeby. W niniejszym artykule omawiana będzie jedynie konsumpcja nadmierna. Można stwierdzić, że życie w społeczeństwie konsumpcyjnym opiera się na permanentnym nabywaniu, spożywaniu, użytkowaniu i pozbywaniu się odpadów, aby następnego dnia ponownie zapoczątkować ten cykl $^{26}$. Konsumpcjonizm odzwierciedla nadmierne nabywanie oraz spożywanie artykułów, a charakterystycznym wzorem zachowania jest spontaniczne dokonywanie zakupów oraz konsumpcja zmysłowa, związana z oglądaniem wystaw i dóbr w sklepach, nieuzasadniona motywem zakupowym ${ }^{27}$. Wówczas konsument, odwiedzając sklepy, czerpie satysfakcję z oglądania witryn ${ }^{28}$. Konsumpcjonizm jest ideologią charakteryzującą się przekonaniami i wartościami związanymi z kapitalistyczną globalizacją, mającą za zadanie przekonać ludzi, że szczęście można osiągnąć, konsumując i posiadając liczne dobra ${ }^{29}$.

Konsumpcjonizm, stymulowany nowymi ośrodkami, polega na nadmiernej konsumpcji, która jest nieuzasadniona biologicznymi i społeczno-kulturowymi potrzebami $^{30}$. Nowymi miejscami konsumpcji są placówki, które bardzo szybko się mnożą i zachęcają do korzystania z przeróżnych artykułów. Zalicza się do nich: centra handlowe, bary szybkiej obsługi, supermarkety, dyskonty, kasyna, parki wodne itp. Naśladują je także różnego rodzaju obiekty sportowe (tenisowe,

24 Związek Stowarzyszeń Polska Zielona Sieć, Dobre zakupy. Poradnik odpowiedzialnego konsumenta, Kraków 2006.

25 J. Farley et al., Quaityl of Life and the Distribution of Wealth and Resources, [w:] Understending and Solving Environmental Problems in the 21st Century, red. R. Costanza, S.E. Jorgensen, Oxford 2002, s. 259.

26 Z. Bauman, Życie na przemiał, Kraków 2005.

27 K-U. Hellman, Das konsumistische Syndrom, [w:] Räume des Konsums über den Funktionswandel von Räumlichkeit im Zeitalter des Konsumismus, red. K-U. Hellman, G. Zurstiege, Wiesbaden 2008, s. 36.

28 W. Wątroba, Homo postmillenius, Wrocław 2008, s. 83.

29 L. Sklair, Iconic architecture and the culture-ideology of consumerism, „Theory, Culture \& Society" 27, 2010, nr 5, s. 135.

30 G. Ritzer, Magiczny świat konsumpcji, przeł. L. Stawowy, Warszawa 2004, s. 22. 
narciarskie, fitness), placówki edukacyjne, luksusowe osiedla, muzea, kina. W tych miejscach dochodzi do połączenia rozrywki z konsumpcją żywności. Innym przykładem jest tworzenie tak zwanego efektu naturalności, polegającego na wycięciu drzew w lesie, aby w tym miejscu postawić nowe osiedle o nazwie „Zielona enklawa”31. Kolejny aspekt to popularyzacja barów szybkiej obsługi, które obecnie zaczynają przeważać ${ }^{32}$, a ich funkcjonowanie opiera się na czterech elementach: policzalności, wydajności, kontroli i przewidywalności.

Barierami zrównoważonego rozwoju, poza konsumpcjonizmem, są: przeludnienie, bieda oraz brak wyobraźni (odpowiedniej wiedzy, edukacji). Konsumpcjonizm spowodował, że istotą ludzkiej egzystencji stała się "potrzeba" konsumowania, co objawia się pod postacią tak zwanej nadkonsumpcji. Opiera się ona na nabywaniu i posiadaniu tanich i nietrwałych dóbr, zgodnie z przekonaniem, że lepiej mieć więcej, mimo że towar jest gorszej jakości, oraz na skupianiu się jedynie na konsumpcji i nagminnym nakłanianiu do nabywania dóbr ${ }^{33}$. Obecnie konsumpcjonizm można również dostrzec w nauce czy sztuce, co wpływa na komercjalizację twórczości ${ }^{34}$. Konsumpcja dziś oznacza inwestycję we własne członkostwo w społeczeństwie ${ }^{35}$. Do cech wskazujących, że konsumpcja przybrała niezrównoważony charakter, należy wzbudzanie u nabywców uczucia pożądania i permanentnego niezaspokojenia. Można się nawet spotkać ze sformułowaniem, że pojawił się przymus kupowania ${ }^{36}$.

Ulegając wszechobecnej promocji, często w nadmiarze konsumuje się produkty, które są bezwartościowe, niezdrowe, często wręcz szkodliwe. Proces produkcji zajmuje dużo czasu, jego promocja również, natomiast już wkrótce po jego zakupie klienci zachęcani są do nabycia nowszej, droższej wersji. Elementem kultury konsumpcyjnej, który ją permanentnie stymuluje, jest reklama. Obecnie pełni ona funkcję ideologicznego instrumentu, a głoszoną przez nią ideologią jest konsumpcja ${ }^{37}$. Reklama wpływa na kształtowanie się człowieka - konsumenta, opierającego się na założeniu, że kluczem do szczęścia jest konsumpcja. Dla konsumenta XXI wieku podstawowymi, najistotniejszymi obiektami pożądania są doznania i przeżycia, realizowane w fabrykach doznań, które stanowią centra handlowa, w których obecnie można znaleźć prawie wszystko. Galeria handlowa jest ogromną przestrzenią imitującą miasto - ma swoiste ulice, alejki czy place, wypełniają

${ }^{31}$ J. Baudrillard, Społeczeństwo konsumpcyjne. Jego mity i struktury, przeł. S. Królak, Warszawa 2006.

32 G. Ritzer, Makdonaldyzacja społeczeństwa, przeł. L. Stawowy, Warszawa 2005, s. 14.

${ }^{33}$ S. Czaja, Becla A., op. cit., s. 41.

${ }^{34}$ O. Leszczak, Paradoksy konsumpcjonizmu. Typologia i lingwosemiotyka, [w:] Życie w konsumpcji - konsumpcja w życiu - konsumpcja życia: współczesny człowiek w społeczeństwie konsumpcyjnym, red. R. Stefański, „The Peculiarity of Man” 2012, nr 15, s. 30.

35 Z. Bauman, To nie jest dziennik, Kraków 2012, s. 317.

${ }^{36}$ J. Baudrillard, op. cit., s. 27.

37 W. Wątroba, Społeczeństwo konsumpcyjne, Wrocław 2009, s. 134. 
ją liczne sklepy, restauracje i kawiarnie, które kuszą zapachem potraw, kolorowym wystrojem. Zmęczony klient ma możliwość odpoczynku w fotelu nad jeziorem, z którego co chwilę tryska fontanna. Można zregenerować swoje siły, poprawić urodę, a nawet odmłodzić się w salonie odnowy biologicznej. Istnieje także możliwość zakupu egzotycznych wakacji w opcji all inclusive $\mathrm{w}$ dostępnych biurach podróży, a także obejrzenia nowej projekcji filmowej w kinie ${ }^{38}$.

Jedzenie jest kolejną potrzebą konieczną do zaspokojenia, kształtowaną przez kulturę konsumpcyjną. Spożywanie jest nie tylko konsumpcją dla przyjemności czy zaspokojeniem podstawowych potrzeb fizjologicznych; jest to również kosztowny i degradujący środowisko naturalne proces produkcji i dystrybucji. Artykuły spożywcze produkowane są na masową skalę, co ma bardzo duży wpływ na jakość oferowanej żywności. Coraz więcej współczesnych konsumentów żywi się artykułami wysoko przetworzonymi, co zmniejsza czas potrzebny na ich przygotowanie, jednakże wywiera negatywny wpływ na ludzki organizm, szkodząc zdrowiu, a w dłuższej perspektywie - zagrażając życiu. Ludzie muszą zacząć zwracać uwagę na jakość kupowanych artykułów spożywczych ze względu na możliwość pojawienia się wielu dolegliwości i chorób ${ }^{39}$. Konsumenci nabywający dobra spożywcze jako głównym kryterium kierują się specyficznymi dla danego produktu walorami smakowymi. Ponadto istotne jest zwrócenie uwagi na skład produktu, aby nie znajdowały się w nim żadne szkodliwe substancje, takie jak: konserwanty, sztuczne barwniki, spulchniacze czy składniki poprawiające smak i zapach ${ }^{40}$. Pojawia się kilka niepokojących tendencji w zakresie konsumpcji żywności:

- wzrost spożycia owoców i warzyw z importu ze względu na ułatwiony dostęp i niższą cenę, co przyczynia się do marnotrawstwa żywności, stając się globalnym problemem;

- zwiększenie się ilości dań gotowych, na co wpływ mają zmniejszenie liczby osób zamieszkujących gospodarstwo domowe oraz aktywność zawodowa wszystkich domowników;

— wzrost wydatków na żywność zakupioną poza domem;

— zwiększona konsumpcja żywności importowanej;

— znaczne spożywanie wody butelkowanej.

Tendencje te są niepokojące, ponieważ marnowanie żywności oraz jej import są negatywnymi zjawiskami, albowiem produkty są transportowane, co w bardzo dużym stopniu przyczynia się do wzrostu $\mathrm{CO}_{2}$ w powietrzu. Nabywanie żywności przetworzonej i częste spożywanie takiej poza domem wpływa niekorzystnie

${ }^{38}$ M. Górnik-Durose, Kupowanie rzeczy, kupowanie doświadczeń - nowe zjawiska w zachowaniach konsumenckich, [w:] Psychologiczne uwarunkowania zachowań ekonomicznych. Przedsiębiorczość - pieniądze - konsumpcja, red. M. Goszczyńska, M. Górnik-Durose, Warszawa 2010, s. 212.

39 T. Sobierajski, Lekko i strawnie, „Sens” 2012, nr 4 (43), s. 92.

40 A. Kurzak-Mabrouk, Spójność działań w obszarze zrównoważonego rozwoju w branży spożywczej, „Optimum. Studia Ekonomiczne” 2017, nr 4 (88), s. 190. 
na ludzkie zdrowie. Produkty te najczęściej są niezdrowe, niezrównoważone, nie są bezpieczne. W składzie mają konserwanty, sztuczne barwniki oraz aromaty. Wymienione trendy przyczyniają się poza tym do powstania wielu negatywnych zjawisk, takich jak zwiększenie zużycia energii poprzez sprzedaż oraz dystrybucję (w przypadku żywności importowanej), a także przechowywanie w domu (w zamrażalniku), oraz wzrost liczby odpadów, a w konsekwencji - zwiększenie produkcji opakowań. Środowisku naturalnemu najbardziej szkodzi produkcja mięsa, a w szczególności wołowiny ${ }^{41}$. Współczesne społeczeństwo konsumpcyjne traktuje punkty usługowe jako apteki, w których dokonuje się zakupów w celu poprawy samopoczucia ${ }^{42}$. Ludzka zachłanność jest główną przyczyną niezrównoważonej konsumpcji. Ta ludzka przywara od zarania dziejów towarzyszy człowiekowi $^{43}$. Historia dowodzi, że w dawnych czasach jedynie uprzywilejowane grupy społeczne mogły sobie pozwolić na bycie zachłannymi, przy czym współcześnie więcej ludzi stać na okazywanie zachłanności. Społeczeństwa dążą do materialnych sukcesów w celu poprawienia swoich warunków życia. Poprzez wzrost gospodarczy ludzie chcą osiągnąć społeczny i osobisty dobrobyt, traktując go jako drogę do jego osiągnięcia.

\section{Warunki równoważenia konsumpcji}

Aby zachowania konsumentów uległy zmianie, konieczne są przeobrażenia wszechobecnej mamiącej reklamy oraz nowych miejsc konsumpcji ${ }^{44}$. Konsumpcja stanie się zrównoważona wówczas, gdy przeprowadzone zostaną odpowiednie zmiany systemowe. Nie jest bowiem możliwe rozwiązanie problemów niezrównoważonej konsumpcji poprzez zmianę indywidualnych zachowań konsumentów. Konsumentów, w zależności od poziomu ekologicznej świadomości, można podzielić na pięć typów ${ }^{45}$ :

- 1. poziom świadomości ekologicznej konsumenta - konsument nie ma wiedzy i świadomości ekologicznej. Podporządkowany jest kultowi konsumpcji, nie oszczędza zasobów naturalnych ani energii;

-2. poziom - konsumentów charakteryzuje niski poziom świadomości ekologicznej. Zasoby oszczędzają tylko ze względu na kwestie ekonomiczne;

${ }^{41}$ EEA, Consumption and the Environment - 2012 Update. The European Environment State and Outlook 2010, Luxembourg 2012, s. 27.

42 Z. Bauman, 44 listy ze świata płynnej nowoczesności, Kraków 2011, s. 112.

${ }^{43} \mathrm{~J}$. Zammit-Lucia, Economic success alone is not enough to improve our wellbeing, 2013, https://www. theguardian.com/sustainable-business/economic-success-not-enough-wellbeing (dostęp: 2.10.2018).

${ }^{44}$ G. Ritzer, Magiczny..., s. 312.

45 S. Zaremba, Ekologia produktów a idee zielonego konsumeryzmu, [w:] Ekologia wyrobów. Materiały konferencyjne, Kraków 1997, s. 57. 
- 3. poziom - konsumentów charakteryzuje znaczna wiedza ekologiczna. Są oni podatni na podnoszenie swojej wiedzy i świadomości ekologicznej. Zależy im, aby być postrzeganymi jako „zieloni konsumenci”, oszczędzający zasoby ze względów ekonomicznych i snobistycznych;

- 4. poziom - konsumenci mający dużą wiedzę ekologiczną, którą stale pogłębiają. Chętnie zmieniają swój styl życia w celu dbania o środowisko. Zasoby użytkują oszczędnie, aby je chronić;

- 5. poziom - konsumenci postulują powrót do natury i wyjątkowo oszczędnie użytkują zasoby naturalne.

Najwyższy poziom świadomości ekologicznej charakteryzuje mieszkańców krajów wysoko rozwiniętych regionów Europy Zachodniej, Ameryki Północnej, Australii i Japonii, jednak paradoksalnie $\mathrm{w}$ krajach tych występuje największe zużycie zasobów naturalnych. W Polsce świadomość ekologiczna zaczyna się kształtować, a najbardziej świadomi są mieszkańcy dużych miast, znajdujący się w średnim przedziale wiekowym, o wysokich dochodach, $\mathrm{z}$ wysokim poziomem wykształcenia, a także młodzież ${ }^{46}$.

Najistotniejszym elementem implementacji nowego paradygmatu konsumpcji jest popularyzacja postawy świadomego konsumenta, odpowiedzialnego, którego charakteryzuje wiedza ekologiczna i prospołeczna wrażliwość. Tego typu konsument, który dokonuje wyborów zrównoważonych, rozumie przyczyny określonych zachowań oraz ich harmonijność z istniejącymi standardami konsumpcji zrównoważonej. W dalszym ciągu częściej można spotkać konsumenta nieświadomego, który ma niski poziom odpowiedzialności. Na tego typu zachowania, które ukazują konsumenta jako osobę o niskim poziomie świadomości i wrażliwości, wpływ wywiera zakupologia. Pojęcie to oznacza, że konsumenci mogą mieć podświadome myśli wpływające na pewne pragnienia i odczucia, potrafiące kierować codziennymi decyzjami o zakupie określonych produktów. Często ludzie zachowują się inaczej, niż deklarują, a wpływ na to ma ich podświadomość. Będąc pod wpływem stresu, lecz także wówczas gdy wszystko układa się prawidłowo, ludzie co innego mówią, ich zachowanie zaś wskazuje na coś zupełnie innego ${ }^{47}$. Aby udało się uzyskać kontrolę nad decyzjami zakupowymi społeczeństwa, należy zaznajomić się z mnogością podświadomych sił rządzących ich zachowaniami nakazującymi im dokonać zakupów.

${ }^{46}$ D. Zaręba, Ekoturystyka, Warszawa 2006, s. 33.

${ }^{47}$ M. Lindstrom, Zakupologia. Prawda i kłamstwa o tym, dlaczego kupujemy, Kraków 2009, s. 31 . 


\section{Podsumowanie}

W wyniku analizy możliwe stało się sformułowanie kilku wniosków. Istotą konsumpcji zrównoważonej są odpowiedzialne ekologicznie i społecznie, świadome decyzje konsumenckie. Do nowego paradygmatu konsumpcji należy włączyć kategorię jakości życia człowieka, który staje się konsumentem. Jednakże nie wystarczy wprowadzić kilka zmian w zachowaniach indywidualnych nabywców, aby przekształcić społeczeństwo konsumpcyjne w zrównoważone. Nawet te osoby, które zaczną w swoim życiu wdrażać zmiany, takie jak eliminowanie spożycia wyrobów mięsnych, minimalizowanie liczby podróży samochodem, realizując te działania indywidualnie, nie będą w stanie wpłynąć na wiele przekształceń. Konieczne jest przeobrażenie społecznych i kulturowych norm na takie, które będą propagować zrównoważony styl życia. Powinien on stać się ogólnoświatowym trendem, atrakcyjnym do naśladowania dla ogółu, aby z konsumpcji niezrównoważonej uczynić społeczne tabu. Niestety istnieje możliwość, że upadek społeczeństw konsumpcyjnych nastąpi wówczas, gdy załamią się systemy ekologiczne, na przykład wzrośnie poziom globalnych temperatur, co przyczyni się do zwiększenia się powierzchni oceanów i mórz. Wówczas ludzkość zostanie zmuszona do znalezienia alternatywy dla konsumpcji niezrównoważonej. Obecnie wydaje się, że musi dość do przełomu, aby społeczeństwo niezrównoważone stało się zrównoważone.

Najłatwiej można realizować zrównoważone zachowania konsumenckie w różnorodnych obszarach strategicznych, będących strefami konsumenckiej aktywności, takimi jak odżywianie się, mobilność, mieszkanie, odzież. Nadrzędnym celem zrównoważonej konsumpcji, warunkującym zrównoważoną jakość życia, jest rzetelna analiza stanu świadomości, co jest niezbędne do zrozumienia potrzeb własnych lub narzuconych. Zachowania charakteryzujące społeczeństwa konsumpcyjne ukazują pewne niepokojące trendy, takie jak antyspołeczne i antyekologiczne zachowania zubożające sferę duchową człowieka. W celu wdrażania zrównoważonej konsumpcji konieczne jest korzystanie ze specjalistycznych instrumentów prawnych, ekonomicznych czy świadomościowych. Konsumentów należy obciążyć odpowiedzialnością - lecz nie w nadmiarze - za dokonywanie zrównoważonych wyborów. Aby jak najwięcej ludzi zaczęło konsumować w sposób zrównoważony, niezbędny jest wzrost świadomości i wrażliwości społecznej w zakresie ekologii, którą można wytworzyć jedynie dzięki edukacji ekologicznej. Edukacja ma na celu kształtowanie młodzieży i nauczanie prawidłowego funkcjonowania w społeczeństwie, które opiera się na wartościach korelujących z koncepcją zrównoważonego rozwoju. Edukacja ekologiczna pozwala wykształtować w społeczeństwie właściwe postawy, mające na celu ochronę zasobów przyrody. 


\section{Bibliografia}

Adamczyk J., Nitkiewicz T., Prognozowanie zrównoważonego rozwoju, Warszawa 2007.

Bańkowski A., Etymologiczny słownik języka polskiego, Warszawa 2000.

Baudrillard J., Społeczeństwo konsumpcyjne. Jego mity i struktury, Warszawa 2006.

Bauman Z., 44 listy ze świata płynnej nowoczesności, Kraków 2011.

Bauman Z., To nie jest dziennik, Kraków 2012.

Bauman Z., Życie na przemiat, Kraków 2005.

Borys T., Jak mierzyć postępy we wdrażaniu zrównoważonego rozwoju?, [w:] Barometr zrównoważonego rozwoju, red. K. Kamieniecki, B. Wójcik, Warszawa 2009.

Borys T., Koncepcja równoważonego rozwoju w naukach ekonomicznych, [w:] Edukacja dla zrównoważonego rozwoju, t. 2, red. B. Poskrobko, Warszawa- Białystok, 2010.

Borys T., Nowe kierunki ekonomii środowiska i zasobów naturalnych $w$ aspekcie nowej perspektywy finansowej Unii Europejskiej, „Ekonomia i Środowisko” 2013, nr 1 (44).

Borys T., Problemy zrównoważonej konsumpcji, [w:] Rozwój zrównoważony, teoria i praktyka, red. B. Fiedor, R. Jończy, Wrocław 2009.

Borys T., Wybrane problemy metodologii pomiaru nowego paradygmatu rozwoju - polskie doświadczenia, „Optimum. Studia Ekonomiczne” 2014, nr 3 (69).

Czaja S., Becla A., Czterech jeźdźców ekologicznej zagłady we współczesnym świecie. Trendy i wyzwania zrównoważonego rozwoju, red. B. Kryk, Szczecin 2011.

Dobre zakupy. Poradnik odpowiedzialnego konsumenta, Kraków 2006.

Dziedzic S., Woźniak L., Ekonomia ekologiczna (zielona) oraz ekonomia endogeniczna we wspieraniu innowacji w rozwoju regionu, Rzeszów 2013.

EEA (European Environment Agency), Consumption and the environment - 2012 update, The European Environment State and outlook 2010, Luxembourg: Publications Office of the European Union.

Farley J., Costanza R., Templet P., Corson M., Crabbe Ph., Esquivel R., Furusawa K., Fyfe W., Loucks O., MacDonald K., MacPhee L., McArthur L., Miller C., O’Brien P., Patterson G., Ribemboim J., Wilson S.J., Quality of Life and the Distribution of Wealth and Resources, [w:] Understending and Solving Environmental Problems in the 21st Century, red. R. Costanza, S.E. Jorgensen Elsevier, Oxford 2002.

Górnik-Durose M., Kupowanie rzeczy, kupowanie doświadczeń - nowe zjawiska w zachowaniach konsumenckich, [w:] Psychologiczne uwarunkowania zachowań ekonomicznych. Przedsiębiorczość pieniadze - konsumpcja, red. M. Goszczyńska, M. Górnik-Durose, Warszawa 2010.

Harrison R., Newholm R., Shaw D., Pressure groups, campaigns and consumers, [w:] The Ethical Consumer, red. R. Harrison, T. Newholm, D. Shaw, London 2005.

Hellman K-U., Das konsumistische Syndrom, [w:] Räume des Konsums über den Funktionswandel von Räumlichkeit im Zeitalter des Konsumismus, red. K-U. Hellman, G. Zurstiege, Wiesbaden 2008.

Jastrzębska-Smolaga H., W kierunku trwałej konsumpcji. Dylematy, zagrożenia, szanse, Warszawa 2000.

Konstytucja RP z 1997 roku (Dz.U. z 1997 r. Nr 78, poz. 483).

Krzystkiewicz M., Rok A., Spacerownik po świadomej konsumpcji - Kraków, Kraków 2008.

Kurzak-Mabrouk A., Spójność działań w obszarze zrównoważonego rozwoju w branży spożywczej, „Optimum. Studia Ekonomiczne” 2017, nr 4 (88).

Leszczak O., Paradoksy konsumpcjonizmu. Typologia i lingwosemiotyka, [w:] Życie w konsumpcji konsumpcja $w$ życiu - konsumpcja życia: współczesny człowiek $w$ społeczeństwie konsumpcyjnym, red. R. Stefański, „The Peculiarity of Man” 2012, nr 15.

Lindstrom M., Zakupologia. Prawda i kłamstwa o tym, dlaczego kupujemy, przeł. M. Zielińska, Kraków 2009. 
Mont O., Plepys A., Sustainable consumption progress: should we be proud or alarmed?, „Journal of Cleaner Production" 2008, nr 16.

Ottman J.A., Green Marketing: Challenges and Opportunities for the New Marketing Age, Lincolnwood 2003.

Poskrobko B., Ekonomia zrównoważonego rozwoju w świetle kanonów nauki, Białystok 2011.

Program działań na rzecz zrównoważonej produkcji i konsumpcji, Ministerstwo Gospodarki 2009, projekt.

Przez zrównoważoną konsumpcję do zrównoważonego rozwoju, Ministerstwo Gospodarki 2012.

Report of the World Commission on Environment and Development, Our Common Future, Oxford, 11.12.1987.

Ritzer G., Magiczny świat konsumpcji, przeł. L. Stawowy, Warszawa 2004.

Ritzer G., Makdonaldyzacja społeczeństwa, przeł. L. Stawowy, Warszawa 2005.

Rogall H., Ekonomia zrównoważonego rozwoju. Teoria i praktyka, przeł. J. Gilewicz, Poznań 2010.

Sklair L., Iconic architecture and the culture-ideology of consumerism, „Theory, Culture \& Society” 27, 2010, nr 5.

Słownik 100 tysięcy potrzebnych słów, red. J. Bralczyk, Warszawa 2005.

Sobierajski T., Lekko i strawnie, „Sens” 2012, nr 4 (43).

Sowell T., Ekonomia dla każdego, przeł. J.M. Fijor, Chicago-Warszawa 2000.

Wątroba W., Homo postmillenius, Wrocław 2008.

Wątroba W., Społeczeństwo konsumpcyjne, Wrocław 2009.

Zammit-Lucia J., Economic success alone is not enough to improve our wellbeing, https://www.theguardian.com/sustainable-business/economic-success-not-enough-wellbeing.

Zaremba S., Ekologia produktów a idee zielonego konsumeryzmu, [w:] Ekologia wyrobów. Materiały konferencyjne, Katedra Technologii i Ekologii Wyrobów Akademii Ekonomicznej w Krakowie, Kraków 8-9 maja 1997 r., Kraków 1997.

Zaremba-Warnke S., Konsumeryzm a procesy integracji i dezintegracji, [w:] Procesy integracyjne i dezintegracyjne we wspótgospodarce, red. B. Polaszkiewicz, J. Boehlke, „Ekonomia i Prawo” 8, 2012, nr 1.

Zaręba D., Ekoturystyka, Warszawa 2006.

\section{Unsustainable consumption and the ways to balance it}

\section{Summary}

As is clear from the title of the article, its subject is the concept of unsustainable consumption and ways to balance it. This phenomenon is negative and is counterbalanced by sustainable consumption, which means a use of goods, as well as services in a way that will enable the assumed goals of a new development paradigm - "sustainable development", which has the features of balancing, sustainability (durability) and self-sustainability. The study was based on literature research in the field of Polish and foreign literature, which describes the phenomenon of balanced and unsustainable consumption. The immediate goal of the article, resulting from the above study, is to show the contradiction between the phenomenon of sustainable consumption and consumerism, and to identify the factors through which the emerging negative phenomenon can be balanced, which ultimately contributes to the quality of society in a clean environment. 